\title{
Annual Meeting of the Royal Society of Canada
}

$\mathrm{T}$ HE Royal Society of Canada held its annual meeting on May 20-24, at the Chateau Frontenac, Quebec. Appropriate to the occasion of the fourth centenary of the discovery of Quebec, the president, M. Léon Gérin, delivered an address on "Jacques Cartier, notre decouvrier". At the same meeting, the Flavelle Gold Medal was presented to Prof. L. V. King for his contributions to mathematical physics, the Lorne Pierce Medal for achievement in literature to F. P. Grove, and the Tyrrel Medal in historical subjects to J. C. Webster.

At the meetings of Section I (French Literature, History, etc.) eighteen papers, and of Section II (English Literature, History, etc.) sixteen papers were presented.

Prof. F. M. G. Johnson, professor of inorganic chemistry in McGill University, was president of Section III (Mathematical, Chemical and Physical Sciences). Owing to the fact that 161 papers were presented, the section was divided into three subsections, which met simultaneously in different rooms. Only a few papers of general interest were presented to the jointmeeting of thesection. Dr.J.S. Plaskett and J. A. Pearce gave a paper in which new evidence was presented indicating that our galaxy is similar in dimensions and structure to the Great Nebula in Andromeda. New concise methods for the rapid transformation of partial second derivatives in thermodynamical problems were presented by Prof. A. N. Shaw. Sydney Sillitoe gave the results of a series of measurements of reflections from the ionosphere using a new automatic method of tuning the antenna of the transmitting circuit which produces a sharp symmetrical wave pulse that was received on the usual type of cathode ray recorder situated two miles from the transmitter.

Among the papers presented by Prof. E. F. Burton and his collaborators, mention should be made of one on supraconductivity in which it was shown that films of supraconducting materials, when coated with thin films of non-supraconducting metals on the outside, lose the power of becoming supraconducting. R. W. McKay presented the results of a long series of careful measurements on the dielectric constant of conducting solutions of sodium chloride, copper sulphate and magnesium sulphate for a frequency of $2 \times 10^{6}$. A new method of quantitative micro-analysis was given by Dr. J. S. Foster and G. O. Langstroth, in which quantities of lead of the order of $10^{-8} \mathrm{gm}$./c.c. were measured in the spinal fluid.

In the Mathematies Sub-Section, Prof. L. V. King presented papers on acoustic radiation pressures on spheres which gave an adequate explanation of the dust figures observed by Prof. R. W. Boyle and his collaborators in the neighbourhood of piezoelectric oscillators operated at supersonic frequencies. The results of mathematical investigations on the effect of viscosity on the trans- mission of acoustic radiation and an extension to the theory of the Rayleigh dise were also presented by Prof. L. V. King. The paper by Prof. A. F. Stevenson on the theory of current flow in heterogeneous earth was of interest to geophysicists.

In the Chemistry Sub-Section, Prof. C. F. Allen and his collaborators read a paper on the preparation and reactions of the simplest $\delta$ ketonic nitriles. Prof. W. Lash Miller read a number of papers on 'bios', and Prof. R. H. Clark, R. G. D. Moore and M. McArthur described the preparation of ten new derivatives of cinnamic acid and ortho-phenyl-phenol. The oxidation of methane at pressures between 100 and 200 atmospheres has been investigated by Prof. E. H. Boomer and J. W. Broughton, who find that methanol is the principal product. Dr. E. W. R. Steacie and E. Solomon read a paper on the decomposition of gaseous ethyl ether at pressures up to 350 atmospheres. Among the papers presented by Prof. Otto Maass, a series of experiments on the properties of liquids and vapours at the critical temperature were of especial interest. In collaboration with $\mathrm{E}$. $\mathrm{H}$. Morris, the new experimental technique which has been devised for measuring such properties as dielectric constant, refractive index and density was described, and it was shown that discontinuity exists between the liquid and vapour heated above the critical temperature.

In the Physics Sub-Section, investigations on the age of certain minerals, as determined from the radii of the rings in pleochroic haloes, were described by Prof. G. H. Henderson. The results are in fair agreement with the ages determined by the uranium-lead content. Prof. J. A. Gray spoke on the scattering of $\mathrm{X}$-rays at small angles; experiments in collaboration with W. E. Bennett have indicated the presence of two distinct types of intense scattered radiation. One type is attributed to diffraction by small prisms, or spheres, and the other to a gas of high molecular weight. R. M. Stewart gave experimental formulæ for the law of decrement for the oscillatory motion of pendulums under atmospheric pressure. The results of a geophysical survey made with torsion balance and magnetic variometers in northern Ontario were presented by A. H. Miller. The presence of a dyke lying under $30 \mathrm{ft}$. or more of overburden, was indicated by both methods used. In a paper read by A. H. Snell, it was shown that about 350 lines in the molecular spectrum of hydrogen gave measurable Stark effect displacements in a field of $90,000 \mathrm{volts} / \mathrm{cm}$. The successful use of photoelectric cells in the experimental determination of the velocity of projectiles was described in a paper by D. C. Rose. Prof. E. F. Burton and his collaborators presented a number of theoretical and experimental papers on hyperfine structure, nuclear moments, X-rays and atomic statistical fields, but space does not permit their discussion. 
Meetings of Section IV (Geological Sciences) were attended by twenty members and some dozen non-members, including officers of the Geological Division of the Quebec Bureau of Mines. Announcement was made of the award of a Royal Society Carnegie fellowship to V. J. Okulitch, of the University of British Columbia and McGill University, who proposes to carry on research at Harvard University.

Twenty-six papers were read or presented by title at the several sessions. Among those which evoked the most interesting discussion may be mentioned papers by J. S. DeLury, on geothermal gradients and on the mechanies of igneous intrusion, and one by Prof. E. L. Bruce on the spectrographic examination of quartz from some gold-bearing quartz veins. Prof. G. H. Henderson gave a summary, illustrated by slides of photomicrographs, of two papers on pleochroic haloes in biotite, and a method of calculating from them the age of the mineral-papers he had presented before Section III of the Society. Prof. Henderson's talk was of considerable interest, and was followed by an informative discussion.

On May 23, twenty members and friends joined in a geological excursion to Levis and vicinity, conducted by Dr. B. T. Denis of the Quebec Bureau of Mines and Prof. T. H. Clark, and on the following day a number of members, at the invitation of Dr. John A. Dresser, visited the Notre Dame Mountains of Quebec, examining especially the rocks of the Serpentine Belt.

The presidential address delivered by Prof. Marie-Victorin before Section V (Biological Sciences) dealt with the flora and ecology of the different sections of the St. Lawrence River. Dr. Huntsman presented two interesting papers on the life and feeding habits of the Fundy salmon and herring respectively; apparently neither of these fish normally migrates so widely as has been supposed. A paper by R. E. Foerster reported reciprocal crosses of the five species of Pacific salmon. Several botanical papers contained results of more than usual significance. One by G. A. Ledingham announced that the zoospores of members of the Plasmodiophorales are biciliate, not uniciliate as hitherto described, and that one cilium is much shorter than the other, indicating less affinity with the Myxomycetes than has been supposed and perhaps, as was suggested in the discussion, descent from algal Heterokontæ. Further evidence of polyphyletic origin of the Fungi was contained in a paper by H. S. Jackson which demonstrated close similarity in the life cycles and sexuality of Uredinales and Rhodophyceæ. Experimental plant embryology was the subject of a paper by Prof. R. B. Thomson, who described how the haustorium of Marsilea embryos develops spherically instead of in the typical cap shape when grown in culture fluid. Prof. G. W. Scarth gave evidence of a remarkable increase in cell permeability (to urea, etc.) in plants which have become hardened to frost. A useful and comprehensive summary of work done in the U.S. Department of Agriculture on cereal rust in relation to the physiology of the host was given by Dr. H. B. Humphrey.

The papers presented to the Medical Sciences Sub-Section covered an exceptionally wide range of topics. Sir Frederick Banting's group have continued their work on silicosis with the development of valuable new methods of attack on the problem, and have found important experimental evidence against the view that sericite, rather than silica, is the harmful substance. Outstanding among a number of communications from the Connaught Laboratories was an exhaustive quantitative study of the diphtheria-antitoxin content of human sera in various circumstances, by Dr. D. T. Fraser. Prof. J. B. Collip and his collaborators presented a series of papers on anterior pituitary hormones, among which Dr. Hector Mortimer's $\mathrm{X}$-ray studies on experimentally produced changes in the rat's skull were noteworthy. Another group of papers was presented by Prof. C. H. Best, and included an account of different crystalline metallic salts of insulin by Dr. D. A. Scott. Prof. F. R. Miller reported on the effects of unipolar faradisation of the caudate nucleus; Dr. G. F. Marrian described improved methods for the isolation and chemical assay of œstrin ; and Prof. C. C. Macklin strikingly demonstrated the existence of communicating pores, in the alveolar walls, between different lobules of the lung.

\section{Obituary}

\section{Dr. Marion I. Newbigin}

$\mathrm{W}^{\mathrm{E}}$ regret to record the death of Dr. Marion Isabel Newbigin, which occurred in Edinburgh on July 20. The removal of her outstanding personality marks a severe loss to geographical science in Great Britain, for she exerted a powerful influence upon the development of geography throughout the present century, by her own writings and teaching as well as by her admirable editing of the Scottish Geographical Magazine since 1902.

Dr. Newbigin, who was born at Alnwick in 1869 , was one of a group of pioneer women who received university training in natural science, and after studying at University College, Aberystwyth and at the University of Edinburgh she graduated as a B.Sc. of London in 1893. Devoting herself to zoology, she quickly established a reputation by her work on pigmentation in animals. She published papers on colour in two groups of birds (Trochilidæ and Nectariniidæ), others upon the pigments of decapod Crustacea and of the muscle of salmon. For this work "and for her book "Colour in Nature, a Study in Biology" she received the degree of D.Sc.(Lond.) in 1898. Her interest in marine fauna is indicated by two papers 